\title{
Inclination State on the Philippine Culture and Arts Using the Appraisal Theory: Factors of Progress and Deterioration
}

\author{
Almighty C. Tabuena * \\ Faculty Member, Senior High School Department, Espiritu Santo Parochial School of \\ Manila, Inc., Manila, Philippines, ORCID: 0000-0002-5875-3617 \\ Carrie Danae S. Bravo \\ Senior High School Department, Espiritu Santo Parochial School of Manila, Inc., Manila, \\ Philippines, ORCID: 0000-0001-5354-5520
}

Feliz Danielle R. Dimalanta

Senior High School Department, Espiritu Santo Parochial School of Manila, Inc., Manila, Philippines, ORCID: 0000-0003-1898-4450

Kate Ashley P. Jusay

Senior High School Department, Espiritu Santo Parochial School of Manila, Inc., Manila, Philippines, ORCID: 0000-0002-6557-0640

\section{Martina Ysabel Vitug}

Senior High School Department, Espiritu Santo Parochial School of Manila, Inc., Manila, Philippines, ORCID: 0000-0003-0949-6666

\begin{tabular}{ll}
\hline \hline Article history & This study aimed to examine the inclination state among selected \\
Received: & Filipinos using the Appraisal Theory in evaluating the appreciation level \\
23.11 .2020 & as an advocacy perspective towards the Philippine culture and arts. This \\
Received in revised form: & $\begin{array}{l}\text { study employed a transformative mixed method research design, both } \\
\text { quantitative and qualitative views were considered through a survey }\end{array}$ \\
01.07 .2021 & questionnaire, an interview, and an assessment process conducted at \\
Accepted: & Espiritu Santo Parochial School of Manila, Inc. and the National \\
04.07 .2021 & Commission for Culture and the Arts, Philippines. They were selected \\
Key words: & through convenience-quota and purposive sampling based on the \\
\hline Appraisal level; & subjects basic knowledge and appreciation of Philippine culture and \\
Appraisal theory; & heritage. The data were analyzed using frequency distribution and content \\
Deterioration; & analysis. Hake factor analysis was also used to measure the appraisal \\
Inclination state; & level in terms of art awareness and appreciation. The results revealed that \\
Philippine arts; & the respondents grasped a high appraisal of the Philippine culture and \\
Philippine culture; & arts. This implied progress factors in terms of art as a form of \\
Progress & communication, museums as the priority tool for preservation and \\
& promotion, and the country's identity and cultural history as to reframe \\
\hline \hline
\end{tabular}

\footnotetext{
* Correspondency: almighty.tabuena@gmail.com
} 
art appreciation. On the contrary, they adapted more to the culture and arts of other countries than to cultural roots due to factors that cause it to deteriorate such as foreign cultures and modern technologies adaptation, lack of knowledge and participation, and the primordialism of ethnocentrism. The researchers assessed that the theory exposed understanding emotions as it is evident that the respondents can reframe others with their beliefs and values towards Philippine culture and arts.

\section{Introduction}

Culture is the characteristics and knowledge of a particular group of people, encompassing language, religion, cuisine, social habits, music, and arts (Zimmermann, 2017). On the other hand, art is the expression or application of human creative skill and imagination, typically in a visual form such as painting or sculpture, producing works to be appreciated primarily for their beauty or emotional power. Philippine Art reflects a society with diverse cultural influences and traditions. Most modern aspects of Philippine cultural life evolved under the foreign rule of Spain and later the United States. Nowadays, technology continues to improve and develop, and the preservation of the traditional culture and arts of the Philippines might be at risk in terms of the Filipinos' inclination and disinclination towards both the Filipino culture and arts. The research is initiated to raise an awareness of the current condition of the Philippine culture and arts, as well as to measure the level of appreciation among the senior high school students and teachers of Espiritu Santo Parochial School of Manila, Inc. and selected government employees of the National Commission for Culture and the Arts about the culture and arts of the Philippines. The researchers also seek to emphasize the importance of the Philippine culture and arts and to identify the different perceptions of the research subjects towards the given topic.

The primary beneficiaries of this study are the following: (a) students and teachers, to value the arts and culture of the Philippines and to engage in activities inclined with the Philippine culture and arts, helping them to be more familiarized and give more importance to the beauty behind the culture and arts of the Philippines, and (b) common people and selected government employees, as both will help to effectively deliver the power that they have to facilitate social interaction and judgment to the respondents, enabling the people to pursue their creative interests and to preserve the culture and arts of the Philippines. The purpose of this study is to know the people's level of awareness and appreciation towards the culture and arts of the Philippines, and to know the impact of their awareness and appreciation towards the research topic, to continue valuing the culture and arts of the Philippines and learning how understanding the Filipinos culture and arts would help the country improve, develop, and preserve its heritage. The future researchers who choose to continue and improve this type of study will get benefit as to how to fill the gaps of their study, develop new instruments to strengthen the validity and importance of conducting a study related to culture and arts, manifest its actualization, and influence other future researchers, aspiring artists, the Filipinos, and the general community. This study can be relevant in making the culture and arts in the Philippines be preserved and valued, as well as influence other people to be inclined and be interested in pursuing art-related courses or any other related fields. This can enlighten them that culture and arts are two of the most important assets of the Philippines, inspiring foreign tourists to also appreciate the arts and cultural heritage of the Philippines. This is also one of the ways of motivating the Filipino people to communicate through the expression of the different forms of art. 


\section{Statement of the Purpose}

In this era, in which technology is advanced, people could already be aware of the culture and arts of other countries without leaving their own country. The culture and arts of the Philippines are both equally essential in the Philippine cultural history as well as on the improvement and development of the Philippine identity.

The objective of this study is to know the level of appreciation, specifically the students, government employees, and teachers on the importance of culture and arts in the Philippines. It also aimed to know the different perceptions of the Filipinos towards the culture and arts of the Philippines using the Appraisal Theory on measuring and evaluating the level of appreciation of the involved respondents. The primary objective of this study is to know if this situation affects the current condition of the culture and arts of the Philippines to the Filipino people. Furthermore, this study aimed to accomplish the following:

(1) Identify the current condition and the inclination state of the Philippine culture and arts among selected Filipinos,

(2) Recognize the factors that make the culture and arts in the Philippines progress or deteriorate; and

(3) Determine the connection of the Appraisal Theory to the level of appreciation of selected Filipinos to the culture and arts of the Philippines.

\section{Literature Review}

\section{Art Awareness}

Art appreciation and understanding begins with awareness; it is about knowing how much interested the Philippines ae in contemporary art and culture (Mercado, 2018) by using art-based activities that would provide ethical awareness and knowledge, learning how to avoid discrimination and racism, and raising the awareness of socio-political issues and indigenous people's concern (Papouli, 2017; Oclos, 2018). The National Commission for Culture and the Arts (2016) focuses on measuring and supporting the impact of culture and arts towards Philippine development and research component in policymaking. Further, the Humanities, Arts and Social Science (HASS) research awareness and how it acted as a powerful predictor of threat perceptions, levels of community activity, and cultural engagement at the local level, however, a significant predictor of core values (Rudd, 2015); the degree of students' awareness of the national heritage to investigate the role of school in raising awareness of the national heritage, and to explore the degree of student satisfaction about that role played in addition to explore the impact of family in predicting the personal interest in the local heritage (Ahmed, 2016).

\section{Art Appreciation}

According to Matamoros and Sumi (2017) on "Spanish artistic appreciation methodology in Japan: learning own culture through art; going to Art Museum with Kindergarten Children”, the value and appreciate arts as early as kindergarten. It emphasized that using the Spanish Artistic Appreciation methodology, children were able to appreciate and interpret arts even though they do not have enough experience. In addition, families welcomed the activities related to arts and appreciate arts as well. Through the research by Abinuman (2017), it stated that arts are under-valued in the Philippines because some corporations or companies only choose the famous artists and do not give chance to those 
who are only starting their journey as an artist. Artists lose their interest in creating content because they would rather choose a job that could give them a steady income.

Leder et al. (2012) also stated that art is a unique feature of the human experience. It involves a complex interplay among stimuli, persons, and contexts. There are different effects for different classes of artworks, the most informative being effect of comprehension are the modern artworks. Sova (2015) emphasized that adults seldom visit museums. If they were to visit, their level of art appreciation depends on their knowledge of arts; most of the visitors to the museums are those who are expert in artistic knowledge. In this case, Ishiguro et al. (2016) stated that learners change their viewing strategies in art appreciation after a course of education in which the mean duration of addiction decreases when one is viewing photographs with recognizable subjects. The critical role of triangulation to create authentic analytical frameworks amidst contradictory participant narratives in sensitive art-based research $(\mathrm{ABR})$ with children make them appreciate or not appreciate what art is (Vanner \& Kimani, 2017). If one truly understands one-piece or form of art, it can be assumed that they are also be able to appreciate it. In order to protect and preserve the Filipino heritage, it should be first planned and observed (Untivero, 2017).

\section{Significance of Art Appreciation}

Art appreciation is important because it helps people to have an open mindset by listening to different opinions, views, and perspectives of other people as well as how art could be interpreted in so many different ways as a dynamic form of expression connecting or communicating to the people on a deeper and personal level; as to why art should be valued and recovered by people, validating how art becomes significant in our lives because of its beauty (Desirazu, 2019; Postma, 2018). On the other hand, Pelowski et al. (2016) presented a theoretical assessment, comparison, and new articulation of a selection of key contemporary cognitive or information-processing-based approaches detailing the mechanisms underlying the viewing of art. Its goal is taking existing theoretical explanations of the psychological processing of art and placing these into a unified visual basis to articulate how, and if, they address specific outcomes from our art experience; the importance of art, and how it has the power to change the world (Eliasson, 2016). It views art as something that can make a difference to everything that we seem to put in mind as the things that are "irrelevant".

\section{Art Progress, Deterioration and Transformation}

As art can make a difference to everything, the colonial mentality is an internalized oppression among Filipinos in which they experience an automatic preference for anything and rejection of anything Filipino. Colonial mentality of the Filipinos and having it can influence any aspect of the Philippine Art community (Mateo, 2016; David, 2013). In this light, the interest in research and writing of local history increased after World War II and this is apparently due to the resurgence of nationalism among Filipinos. Prior to that, the history of the Philippines and bibliographies of Filipiniana materials were written mostly by foreigners; it is about how the past affects the future on how the Filipinos were influenced by the different countries that colonized us in the past (Perez \& Templeza, 2012). It also affects the progress and transformation of history, culture, and heritage. On the contrary, Chiakiamco (2010) reviewed some of the issues that seemed to be a worthy endeavor if only to remind ourselves that, "for the Philippine Art Scene, there is still a lot more work to be done".

From these reviews pertaining to awareness, appreciation, importance, and history of arts as well as why people need to preserve and appreciate art in its different forms and why people 
should be aware of its importance and impact to the world, this study emphasized the different perspectives of the people and the artists' points of view about any forms of art. The researchers aimed to understand the level of awareness and appreciation people have for art, to determine how certain methodologies helped assess and evaluate the current condition of art-related resources in many places, and to give emphasis on the different interpretations of people towards culture and arts, focusing on the assessment of the current status of the arts and culture in the Philippines. Other reviews employed different kinds of approach in evaluating the importance of art awareness and appreciation that can be used by the researchers to widen and deepen different kinds of perspectives in expressing all forms of art, such as the perspective of children, adults, working students, artists, and common people. Creative methodologies can also be used by the researchers to strengthen the results of the assessment's accuracy and validity, such as the use of philosophical approaches, practical evaluation, observations, theoretical and conceptual approaches, as well as the specific use of developed instruments by other researchers.

\section{Methodology}

\section{Research Design}

This study employed a transformative mixed method research design as both qualitative and quantitative views were considered. This methodology for conducting research involves collecting, analyzing, and integrating quantitative and qualitative research methods through a survey and questionnaire (Baraceros, 2016; Creswell, 2012). The researchers assessed the level of appreciation and importance of the culture and arts subject towards the Philippine culture and arts as well as its current condition using a theoretical lens called the Appraisal Theory. This lens becomes an advocacy perspective that shapes the types of questions asked, inform how data are collected and analyzed, and provides a call for action or change (Creswell, 2009).

\section{Participants of the Study}

The sampling techniques used by the researchers are the following: (a) quota sampling, in which the population is divided into two strata and sample elements are selected from each stratum. The similar characteristics the subjects possess is their level of appreciation of the culture and arts in the Philippines, but their level of knowledge and appreciation vary from their different perceptions, and (b) convenience sampling, in which 5 respondents are added to support the overall population. The research was conducted at Espiritu Santo Parochial School of Manila, Inc. and the National Commission for Culture and the Arts (NCCA), a government agency, both located in Metro Manila, Philippines. The population selected is based on the subjects' basic knowledge and their level of appreciation of the culture and arts in the Philippines. These subjects are selected in each specific strata from each classified stratum composed of students and teachers. The subset of the population of all combined respondents is 85 in total, with 60 students in the senior high school, 20 teachers, and 5 government employees of the National Commission for Culture and the Arts (NCCA). The senior high school students and teachers of the Espiritu Santo Parochial School of Manila, Inc. underwent a survey through a questionnaire.

A total of 5 selected government employees from the National Commission for Culture and Arts were interviewed, following the transformative mixed method research design of the study, in which a theoretical lens was used by the researchers to conduct the interview. The 
researchers selected the senior high school students to gain knowledge about their level of appreciation for the culture and arts in the Philippines since they belong to the youth and one of the target respondents of the study is the youth. The teachers also helped the study based on their different perceptions in line with the specific subjects they teach and the different fields they belong to. The government employees supported and expounded the knowledge of the researchers about the study and provided more specific answers based on their inclination to the research itself. In addition, the research was only conducted in Metro Manila, specifically at Espiritu Santo Parochial School of Manila, Inc. and the National Commission for Culture and Arts for the convenience and purpose of the researchers to accomplish the study within a timeframe.

\section{Research Instrument}

The researchers used two instruments to gather data, the survey questionnaire and interview process (protocol). In terms of the survey questionnaire, it was first developed by the researchers, it was further evaluated and validated by three experts at Espiritu Santo Parochial School of Manila, Inc., one as the Filipino Coordinator, another one as the Araling Panlipunan Coordinator, and one as the Vice Principal for Academics from the High School Department, as they are the appropriate professionals to examine the developed survey questionnaire pertaining to culture and arts. The survey questionnaire was distributed for the survey process among 80 respondents. The researchers provided questions about the specific categories of Philippine culture and arts, and the appreciation and depreciation of Filipinos towards the same topic to the selected 5 NCCA government employees as the respondents to be interviewed regarding their different and personal perceptions, they served as the supporting respondents for the survey results done by the senior high school students and teachers at Espiritu Santo Parochial School of Manila, Inc.

\section{Data Gathering Procedure}

The first phase of the transformative mixed method research design is allotted for the survey questionnaire, interview questions for the second phase, and the assessment process for the third phase (Nova Southeastern University, 2020). The researchers used the following tools and techniques for the given study: (a) questionnaire, the researchers developed and validated questions in terms of the specific categories of the Philippine culture and arts in the conduct of the survey in determining the respondents' level of appreciation towards the topic; (b) interview questions, to assess and evaluate specific answers of the selected respondents in determining the different perceptions towards the Philippine culture and arts through a formal and informal (face-to-face and/or social media) interviews; and (c) assessment, to assess and evaluate the responses of the respondents using the Appraisal Theory where perceptions were emphasized in this stage. Based on the theory that would be used to analyze the respondents' perceptions towards the culture and arts in the Philippines, the researchers used the Appraisal Theory or "Lazarus Theory", one of the Cognitive Appraisal Theories of Emotion by Lazarus (1991), originally started by Arnold (Scherer, Shorr, \& Johnstone, 2001). It deals with how people assess a significant event or thing in their lives, and how they think they should deal with it.

The theory would explain how the respondents' specific answers to the interview questions regarding the culture and arts in the Philippines expose their "understanding emotions" for the researchers to evaluate their perceptions using the theory's cognitive approach. Based on the statement of the problem in connection with the theory, the researchers assessed the level of appreciation of the Filipinos towards the Philippine culture and arts. The researchers would 
use the term "reframing", a complex schema of unquestioned beliefs and values that people use to infer meanings and understand "unspoken assumptions" of the respondents. This could be a form of a theoretical lens identifying and understanding the different beliefs or other aspects in a certain frame.

\section{Data Analysis}

The researchers analyzed the relationship between the results of the respondents' responses and the meanings connected to the variables through content analysis. Using the descriptive statistics, the researchers have weighed the inclination and disinclination of Filipinos towards the Philippine culture and arts. The data gathered had been distributed into different parts or categories (survey results of the different senior high school academic strands and teachers at Espiritu Santo Parochial School of Manila, Inc., and the interview responses of the National Commission for Culture and the Arts employees. The researchers have constructed frequency distribution tables for each survey question while interview questions were also interpreted and analyzed individually. The tallied results were converted to percentages and weighted means, drawing meanings of the level of appreciation of Filipinos towards the Philippine culture and arts using the Appraisal Theory which is based on the respondents' different observations and perceptions. On the other hand, to measure the appraisal level, the researchers used the Hake factor analysis wherein the researchers obtained the value of normalized gain (gain of average) to interpret and analyze the level in the art awareness and appreciation of the respondents (Tabuena, 2019; Tabuena, Bartolome \& Taboy, 2020). Further, the respondents' answers could then be reframed by means of their "cognitive and emotional capacities". Thus, the resulting analysis would make varied meanings from the combined specific answers of the respondents by taking a limited number of facts and inferring or assuming other detail to be able to make sense of things (Watzlawick, Weakland, \& Fisch, 1974).

\section{Results and Discussion}

\section{Current Inclination and Disinclination Status on the Philippine Culture and Arts}

Table 1. Art Awareness in the Philippine Culture and Arts

\begin{tabular}{|c|c|c|c|c|c|}
\hline \multirow{2}{*}{ Indicators } & \multicolumn{2}{|l|}{ Evident } & \multicolumn{2}{|c|}{ Not Evident } & \multirow{2}{*}{ Weighted Mean } \\
\hline & $\mathrm{F}$ & $\%$ & $\mathrm{~F}$ & $\%$ & \\
\hline $\begin{array}{l}\text { Senior High School } \\
\text { Students }{ }^{1}\end{array}$ & 55 & 92.00 & 5 & 8.00 & \\
\hline Teachers $^{2}$ & 20 & 100.00 & 0 & 0.00 & \\
\hline Total & 75 & 93.75 & 5 & 6.25 & $1.938(\mathrm{HA})$ \\
\hline
\end{tabular}

Table 1 shows that out of the 60 senior high school students, 55 answered yes and they are aware of the Philippine culture and art; and 5 of them answered no. On the other hand, all the respondents from the teachers of the Espiritu Santo Parochial School of Manila, Inc. are aware of the Philippine culture and arts. In connection with the Appraisal Theory, their level of art awareness towards the culture and arts in the Philippines showed a positive appraisal (high appraisal). 
Table 2. Art Experience through Museums, Exhibits, and Theaters

\begin{tabular}{|c|c|c|c|c|c|c|c|}
\hline \multirow{2}{*}{ Indicators } & \multicolumn{2}{|c|}{ Museums } & \multicolumn{2}{|c|}{ Exhibits } & \multicolumn{2}{|c|}{ Theaters } & \multirow{2}{*}{ Weighted Mean } \\
\hline & $\mathrm{F}$ & $\%$ & $\mathrm{~F}$ & $\%$ & $\mathrm{~F}$ & $\%$ & \\
\hline $\begin{array}{l}\text { Senior High School } \\
\text { Students }^{1}\end{array}$ & 42 & 70.00 & 18 & 30.00 & 12 & 20.00 & \\
\hline Teachers $^{2}$ & 16 & 80.00 & 5 & 25.00 & 10 & 50.00 & \\
\hline Total & 58 & 72.50 & 23 & 28.75 & 22 & 27.50 & 1.425 (MA) \\
\hline Rank & $1(\mathrm{E})$ & & 2 & & 3 & & \\
\hline
\end{tabular}

Note. ${ }^{1} \mathrm{n}=60 ;{ }^{2} \mathrm{n}=20 ; \mathrm{N}=80 ; \mathrm{F}=$ frequency; $\%$ = percentage; $\mathrm{E}=$ evident HA (High appraisal) $=2.000-1.520$; MA $($ Moderate appraisal $)=1.231-1.519 ;$ LA $($ Low appraisal $)=1.000-1.230$

Based on Table 2, the question states the respondents' art experience through going to different museums in the Philippines. The respondents mostly shared museums such as National Museums in Manila. In relation to the Appraisal Theory, it shows that these museums are the most accessible for the respondents resulting in their high appraisal level towards visiting museums. Most of the respondents had experienced going to museums such as the National Museum. But there are also different museums, theaters, and exhibits from different places in Metropolitan Manila that are visited by some of the respondents.

Table 3. Art-related Government Agencies related to Philippine Culture and Arts

\begin{tabular}{|c|c|c|c|c|c|c|c|c|c|}
\hline \multirow[t]{2}{*}{ Indicators } & \multicolumn{4}{|c|}{$\begin{array}{l}\text { Evident } \\
\text { NCCA }\end{array}$} & \multicolumn{2}{|c|}{$\mathrm{NHCP}$} & \multicolumn{2}{|c|}{ Not Evident } & \multirow{2}{*}{$\begin{array}{l}\text { Weighted } \\
\text { Mean }\end{array}$} \\
\hline & $\mathrm{F}$ & $\%$ & $\mathrm{~F}$ & $\%$ & $\mathrm{~F}$ & $\%$ & $\mathrm{~F}$ & $\%$ & \\
\hline $\begin{array}{l}\text { Senior High School } \\
\text { Students } 1\end{array}$ & 26 & 43.33 & 23 & 38.33 & 12 & 20.00 & 17 & 28.33 & \\
\hline Teachers $^{2}$ & 14 & 70.00 & 20 & 100.00 & 16 & 80.00 & 0 & 0.00 & \\
\hline Total & 40 & 50.00 & 43 & 53.75 & 28 & 35.00 & 17 & 21.25 & 1.463 (MA) \\
\hline Rank & 1 & & & & & & 2 & & \\
\hline
\end{tabular}

Table 3 shows the awareness of the respondents of the government offices related to arts. Based on the table, among the National Commission for Culture and the Arts (NCCA) and the Cultural Center of the Philippines (CCP), NCAA was the most known agency. National Historical Commission of the Philippines (NHCP) was the least known agency. In relation to the Appraisal Theory, the level of an appraisal on the art-related government agencies in the Philippines was moderate. Most of the respondents were familiar and knowledgeable about the different government agencies, also affecting their level of awareness towards the Philippine culture and arts. In this case, a moderate appraisal was inferred as some of the respondents answered they are not familiar with the culture and art-related government agencies in the Philippines.

Table 4. Inclusion of Art-related Courses in the School

\begin{tabular}{|c|c|c|c|c|c|}
\hline \multirow{2}{*}{ Indicators } & \multicolumn{2}{|c|}{ Evident (E) } & \multicolumn{2}{|c|}{ Not Evident (NE) } & \multirow{2}{*}{ Weighted Mean } \\
\hline & $\mathrm{F}$ & $\%$ & $\mathrm{~F}$ & $\%$ & \\
\hline $\begin{array}{l}\text { Senior High School } \\
\text { Students }^{1}\end{array}$ & 54 & 92.00 & 6 & 8.00 & \\
\hline Teachers $^{2}$ & 20 & 100.00 & 0 & 0.00 & \\
\hline Total & 74 & 92.50 & 6 & 7.50 & 1.925 (HA) \\
\hline
\end{tabular}

Note. ${ }^{1} \mathrm{n}=60 ;{ }^{2} \mathrm{n}=20 ; \mathrm{N}=80 ; \mathrm{F}=$ frequency; $\%=$ percentage; HA (High appraisal) $=2.000-1.520 ;$ MA $($ Moderate appraisal $)=1.231-1.519 ; \mathrm{LA}($ Low appraisal $)=1.000-1.230$

Table 4 shows that the respondents were into consideration and prioritize of including artrelated courses in the basic education. According to them, art-related courses in the school 
should enhance every art form, particularly visual arts, while some of them preferred museum appreciation, music, personal development, and theater courses. The following are the other art-related courses preferred to be included in the curriculum: folk dances, indigenous art, art and design, organizations, preservation, performing arts, exhibits, and local art courses. In relation to the Appraisal Theory, the respondents' emotion or appraisal towards the culture and arts in the Philippines has a strong foundation in choosing which aspect/s in the culture and arts of the country should be prioritized in schools, and how their suggestions and different opinions could reframe the schools' plans on putting up their priority courses and/or program.

\section{Factors of Progress and Deterioration in the Philippine Culture and Arts}

Table 5. Life Aspect Reflections of Philippine Culture and Arts

\begin{tabular}{lllllllll}
\hline \multirow{2}{*}{ Indicators } & Social & \multicolumn{2}{c}{ Political } & \multicolumn{2}{c}{ Educational } & \multicolumn{2}{c}{ Livelihood } \\
& $\mathrm{F}$ & $\%$ & $\mathrm{~F}$ & $\%$ & $\mathrm{~F}$ & $\%$ & $\mathrm{~F}$ & $\%$ \\
\hline Senior High School Students $^{1}$ & 27 & 45.00 & 8 & 13.33 & 25 & 41.67 & 11 & 18.33 \\
Teachers $^{2}$ & 13 & 65.00 & 2 & 10.00 & 8 & 40.00 & 4 & 20.00 \\
Total & 40 & 50.00 & 10 & 12.50 & 33 & 41.25 & 15 & 18.75 \\
Rank & 1 & & 4 & & 2 & & 3 & \\
\hline
\end{tabular}

Note. ${ }^{1} \mathrm{n}=60 ;{ }^{2} \mathrm{n}=20 ; \mathrm{N}=80 ; \mathrm{F}=$ frequency; $\%=$ percentage

Table 5 shows that the majority of the respondents view the social aspect as a reflection of Philippine culture and arts in the life aspect of individuals which meant for them that the culture and arts in the country is a means of communication. In connection with the Appraisal Theory, the answer of the respondents made "art as a form of communication" because of their individual experiences that changed them and their way of life. Further, according to the respondents, they considered their daily life, a poster for projects, historical background in Filipino films, and inspiration for college as the specific aspect in their life where culture and arts in the Philippines reflect them as a person; others responded in terms of communicating with others, loving for the country, knowing about the culture and arts, sharing different culture, and familiarizing MAPEH (music, arts, physical education, and health).

Table 6. Priority Resources for the Enhancement of Philippine Culture and Arts

\begin{tabular}{lllllllll}
\hline \multirow{2}{*}{ Indicators } & \multicolumn{2}{c}{ Dance Studios } & \multicolumn{2}{c}{ Museums } & \multicolumn{2}{c}{ Recording } & \multicolumn{2}{c}{ Theater } \\
& $\mathrm{F}$ & $\%$ & $\mathrm{~F}$ & $\%$ & $\mathrm{~F}$ & $\%$ & $\mathrm{~F}$ & $\%$ \\
\hline Senior High School Students $^{1}$ & 8 & 13.33 & 32 & 53.33 & 7 & 11.67 & 21 & 35.00 \\
Teachers $^{2}$ & 2 & 10.00 & 12 & 60.00 & 1 & 5.00 & 9 & 45.00 \\
Total & 10 & 12.50 & 44 & 55.00 & 8 & 10 & 30 & 37.50 \\
Rank & 3 & & 1 & & 4 & & 2 & \\
\hline
\end{tabular}

Note. ${ }^{1} \mathrm{n}=60 ;{ }^{2} \mathrm{n}=20 ; \mathrm{N}=80 ; \mathrm{F}=$ frequency; $\%=$ percentage

Table 6 shows that museums should be prioritized first in the improvement and development of the culture and arts in the Philippines. In this case, based on the opinions of respondents, it is reflected that their purpose is to preserve the culture, arts, traditions, and historical places. In relation to the Appraisal Theory, people are highly aware that culture and arts must be preserved. This shows that their appraisal is high, and they can influence and reframe other people to appreciate their cultural roots more even to the next generations. On the other hand, there is also a need to prioritize the theater in the Philippines and a minimal emphasis on dance studios and recording. Other reasons why art-related resources should be prioritized first in the improvement and development of the culture and arts in the Philippines include respect for each gender, awareness of others, relevance in our time, preserve great singers, and creativity. 


\section{Priority Field of Arts in the Philippines}

One of the National Commission for Culture and the Arts (NCCA) employees suggested prioritizing the Philippine traditional arts and communities which is on the brink of becoming extinct in terms of Filipino weaving, architecture, performing arts, and its allied arts. Filipino artists, cultural workers, and historians need to be recognized for their outstanding achievements in relevant fields that have made an impact and significant contribution to Philippine culture and arts. The narrative regarding the respondents' opinions as to what field of arts in the Philippines should be prioritized first based on the chosen government employees shows their individual preferences about their choice of fields. Most of their answers only vary from the traditional arts. Using the Appraisal theory, the researchers inferred that the respondents are aware that their own opinions are not merely suggestions but also a need for recommendations.

Table 7. Adaptation to Popular Culture instead of Traditional Culture and Arts

\begin{tabular}{llllll}
\hline \multirow{2}{*}{ Indicators } & Evident (E) & \multicolumn{3}{c}{ Not Evident (NE) } & \multirow{2}{*}{ Weighted Mean } \\
\hline Senior High School & F & $\%$ & F & $\%$ & \\
Students $^{1}$ & 35 & 58.33 & 25 & 41.67 & \\
Teacher $^{\text {22 }}$ & 17 & 85.00 & 3 & 15.00 & \\
Total & 52 & 65.00 & 28 & 35.00 & $1.925(\mathrm{E})$ \\
\hline
\end{tabular}

Note. ${ }^{1} \mathrm{n}=60 ;{ }^{2} \mathrm{n}=20 ; \mathrm{N}=80 ; \mathrm{F}=$ frequency; $\%=$ percentage; $\mathrm{E}$ (Evident) $=2.000-1.520 ;$ ME (Moderately evident $)=1.231-1.519 ; \mathrm{NE}($ Not evident $)=1.000-1.230$

Table 7 shows that the majority of the respondents adopted the popular culture and arts more than traditional culture and arts yet, according to the respondents, there is a minimal response regarding the most evident pop culture in the Philippines with a frequency of $23(28.75 \%)$. According to the respondents' answers, popular culture and arts are invading the country which is Korean pop culture and Hollywood film productions. Most of the respondents chose Hypebeast and Korean Pop Culture and Drama as the most adapted culture of the Filipinos in the present. While some of the respondents responded to Hollywood Films, Digital Arts, Pop music, and street arts.

Table 8. Awareness to Value and Preserve the Philippine Culture and Arts

\begin{tabular}{|c|c|c|c|c|c|}
\hline \multirow{2}{*}{ Indicators } & \multicolumn{2}{|c|}{ Evident (E) } & \multicolumn{2}{|c|}{ Not Evident (NE) } & \multirow[b]{2}{*}{ Weighted Mean } \\
\hline & $\mathrm{F}$ & $\%$ & $\mathrm{~F}$ & $\%$ & \\
\hline $\begin{array}{l}\text { Senior High School } \\
\text { Students }{ }^{1}\end{array}$ & 50 & 83.00 & 10 & 17.00 & \\
\hline Teachers $^{2}$ & 17 & 85.00 & 3 & 15.00 & \\
\hline Total & 67 & 100.00 & 13 & 100.00 & 1.838 (HA) \\
\hline
\end{tabular}

Table 8 shows that majority of the respondents are aware that it is a priority to value and preserve the Filipino tradition as well as the culture and arts of the Philippines. In this case, the respondents' individual opinions as to why Filipinos should continue to preserve and value the culture and arts in the Philippines is that it serves as the country's own identity, and it is part of the Filipinos' cultural history. In connection with the theory, the respondents are highly aware of the importance of the culture and arts in the Philippines that is why their appraisal is also high because they have the power to reframe other people of their age and even the next generations towards appreciating their cultural heritage. 


\section{Factors Affecting the Awareness and Indifference on the Philippine Culture and Arts}

According to the National Commission for Culture and the Arts interviewees, the factors that make Filipinos neglect the Philippine culture and arts are their use of social media, television, and the internet where foreign cultures are readily accessible to the youth. Filipinos also neglect the Philippine culture and arts because of their lack of knowledge and participation, and the primordialism of ethnocentrism. Filipinos should develop, produce, disseminate, and liberalize access to information on Filipino culture, and establish knowledge development centers and institutes for living traditions and for building capacities of Filipinos to be inclined in their cultural heritage. The youth nowadays do not grasp the importance of culture, arts, and heritage, especially if it does not affect them at first-hand; in this case, social media can help and is a big factor in the awareness of the public. Based on the narrative social media is the biggest factor of the Filipinos' indifference towards the Philippine culture and arts, and that they lack knowledge and participation in culture and arts-related activities presented to them. In connection with the Appraisal Theory, most of the Filipinos' negligence on the culture and arts in the Philippines results in their unawareness and depreciation towards their cultural heritage.

\section{Connection of the Appraisal Theory to the Level of Art Appreciation on the Philippine Culture and Arts}

\section{Advice to the Youth in the Promotion and Preservation of the Philippine Culture and Arts}

Based on the interview, the youth should first need to appreciate their own culture and arts; that is, culture, being their traditions like saying "po" and "opo", and "pagmamano", and arts, being those works of their very own national artists mostly known to them. The youth should have a deeper understanding of the Philippine culture and arts as to study and appreciate it as it helps them value their cultural heritage; they must take part in all of the activities that maintain the Filipinos' culture in order to prevent its extinction, to use social media as a venue for its promotion and preservation, and to practice Filipino culture in their everyday lives. They should recognize cultural heritage tourism as an upcoming industry by building cultural resources with an adaptation of scientific and technological knowledge to local circumstances, as well as forming a partnership between local and global bodies. In connection with the Appraisal Theory, the respondents could reframe the perceptions of the youth in terms of their professional knowledge towards the culture and arts in the Philippines. The respondents' individual opinions show how they could come up with different ways to promote and preserve the culture and arts in the Philippines and how their answers could influence the youth.

In this light, one of the National Commission for Culture and the Arts (NCCA) employees suggested the promotion and preservation of the ancient Baybayin writing, since this is a security mark and an important key to accessing the Philippine culture. In addition, it is suggested to continue and expand cultural mapping across the country and create a registry for artists and cultural workers. On the other hand, it is also suggested, either tangible or intangible, to promote Filipino cuisine, fashion, arts, and crafts. The narrative regarding the government employees' preferences as to what specific culture in the Philippines would they want to promote to other countries shows their different suggestions about their personal preferences. Some answered Baybayin writing, while others prefer traditional Filipino fashion, crafts, and cuisine. Using the Appraisal theory, the researchers inferred that the respondents are aware that their preferences are becoming the most extinct culture in the 
Philippines; that is why they came up with different perceptions that their preferences should be prioritized first.

\section{Dedication in Fulfilling the Promotion and Preservation of the Philippine Culture and Arts}

The preservation of the Philippine culture and arts is very important because it can affect lots of things; to successfully promote and preserve it is to operate and fulfill the objectives of the National Commission for Culture and the Arts and serve the purpose of its mandate. According to the interviewees, being a government employee working in an agency that promotes the culture and arts in the Philippines is not only a job but also personal advocacy. The measure of one's dedication to the promotion and preservation of the culture and arts in the Philippines is understanding the nature and importance of the Filipino cultural heritage. Through understanding, they will be able to share their knowledge with others. On the other hand, promotion, and preservation simply by means of speaking Filipino and appreciating the Filipino crafts, cuisine, fashion, and buying Filipino products most of the time. In connection with the Appraisal Theory, the respondents' relationship with their job greatly affects their dedication towards the mandate of their company. Because of this, they value more the culture and arts in the Philippines, and their level of appreciation also impacts their level of appraisal towards the Philippine culture and arts.

\section{Exercise of Power in the Promotion and Preservation of the Philippine Culture and Arts}

It is the mandate of the National Commission for Culture and the Arts (NCCA), so all employees, regardless of which rank or position, the duty-bound to fulfill its legalities and policies - to participate and share information on the activities in the context of cultural preservation (such as Facebook, Instagram, and other social media sites providing exposure to promote it) which are both valuable for the artistic image of the country and its heritage. On the other hand, promotion and preservation take place in terms of communication with other people to raise their awareness, by setting as an example to younger people as an ordinary NCCA government employee in which this power begins at home and then at the workplace. In connection with the Appraisal Theory, the respondents could have their different ways of exercising their power to reshape or reframe other people into appreciating and preserving the culture and arts in the Philippines in a much deeper sense.

\section{Proposal Plans to Boost the Awareness and Interest of the Filipinos in the Arts}

Filipinos should start campaigns for cultural awareness at home and disseminate information, conduct meetings, and exhibitions which can be held in museums or libraries accessible to young people. They should maintain and preserve their cultural heritage that can lead to increased awareness and pride among people in their history by initiating workshops on Sustainable Tourism Development in world heritage sites, supporting the aim and advocacy of the commission, and supporting the local government units (LGU) in its local cultural council's projects. In connection with the Appraisal Theory, the respondents could have the power to manifest these proposals and reframe those people who lack awareness of the culture and arts in the Philippines, so these people could also appreciate their cultural heritage. 


\section{Assessment of the Perspectives in the Philippine Culture and Arts}

Immersing one's self in the arts made people appreciate and better understand the Philippine cultural heritage in terms of its nature and importance as the NCCA increases the government's effort for the promotion of values that fosters the common good of the Filipinos' preservation of the Philippine culture and arts. Using the Appraisal Theory, it could be said that their job gives a positive effect on their perception towards the culture and arts in the Philippines; their different positions, helps them appreciate more the Philippine culture and arts. On the other hand, Philippine culture and arts is diverse, a mix or combination of Japanese, Chinese, and American culture, through colonization, the Filipinos were influenced by these nations, and they still carry them up to this day. Even if this is the case, culture and its heritage reflect and shape values, beliefs, and aspirations thereby defining people's national identity as it is important to preserve the Filipino cultural heritage and keep the integrity of the people. Using the Appraisal theory, their perception affects how they describe the Philippine culture and arts as a diverse culture.

\section{Conclusion and Recommendation}

Specifically, in urban places like Manila, Filipinos are very much aware of the culture and arts in the Philippines. In connection with the Appraisal Theory, their level of art awareness towards the culture and arts in the Philippines showed a positive appraisal. The majority of them still visit museums and theaters around Metro Manila, and the most common visited museum is the National Museum, which includes several national museums in the Philippines such as the ethnographic, anthropological, archaeological, and visual arts collections. It also is shown that museums are the most accessible for the respondents resulting in their high appraisal level towards visiting museums. The respondents are knowledgeable of the government agencies related to the culture and arts in the Philippines, but there are also a few respondents who consider themselves unaware of the mentioned government agencies related to the culture and arts in the Philippines. The level of an appraisal on the art-related government agencies in the Philippines was average as some of them were not familiar with it. The respondents highly suggested prioritizing art-related courses in schools. Their emotion or appraisal towards the culture and arts in the Philippines has a strong foundation in choosing which aspect/s in the culture and arts of the country should be prioritized in schools, and how their suggestions and different opinions could reframe the schools' plans on putting up their priority courses and/or program.

The factors that make the culture and arts in the Philippines progress or deteriorate include the respondents' overall answer that there is a need to preserve it as it is part of the Filipinos' identity which makes the country progress as one nation. On the other hand, the factors that make the culture and arts of the Philippines deteriorate is the Filipinos' adaptation to the foreign culture and arts: adapting to foreign cultures by imitating other foreign people manner of speaking (vlogging, and songwriting), attitudes and behavior; adapting to Korean culture specifically on their music, TV shows, and cuisine; adapting to Japanese culture mainly on their cuisine and music; adapting to the American culture specifically on their music, movies, literature, and art; adapting on foreign people fashion like streetwear and hypebeast as the new luxury; and adapting to modern technology. On the other hand, the following are the factors that make Filipinos adapt to their own traditional culture: treating the culture as their own identity which distinguishes us from other countries, saying that the culture and arts are the country's sources in every way, believing that it is an influence of the patriotic and highly academic people which makes it a living legacy for Filipinos; preserving the Philippines heritage to know the culture and arts of specific indigenous people in terms of art awareness 
and understanding; and living it as their nationalistic root.

The connection of the Appraisal Theory to the level of appreciation of the Filipinos to the culture and arts of the Philippines was used to analyze the respondents' perceptions towards the culture and arts in the Philippines. The researchers assessed a significant event, which is the respondents' perception, appraisal, and mediation on their level of awareness and appreciation. The theory strengthened the respondents' answers to specific questions and explained how their answers also exposed their "understanding emotions" towards the culture and arts in the Philippines. The majority of them have the capability to "reframe" other people with their own beliefs and values that they also used to infer meanings while answering the survey and interview.

The following recommendations could help in developing new and improved theoretical and conceptual frameworks to assess and evaluate the level of awareness and appreciation of different people with different cultures while simultaneously adapting to the ever-changing society:

Social media is one of the best ways for things to easily be passed through. Filipinos should maximize the use of this platform for them to be engaged in preserving their own culture. They could do so by means of taking part in various cultural and art-related activities that would let them maintain their cultural heritage and prevent its extinction. On the other hand, older people have the power to educate the youth about the things that would lead to promoting and preserving the culture and arts in the Philippines, such as practicing basic cultural traditions and patronizing traditional Filipino products as well as its ethnic roots. Government employees being part of any culture and art-related agencies play a big part in the country in fulfilling their duty to use their power to support the culture and arts in the Philippines. They could start cultural awareness campaigns that could easily be accessed by people, especially the youth. They could conduct meeting exhibitions in museums and other places to give awareness to everyone.

Since this study only focused on the appreciation of the culture and arts in the Philippines, the researchers highly recommended that further studies should be carried out on students from other schools, faculties, and also government employees to see whether there are any similarities, differences, and even research gaps on the findings. It is also recommended that further studies inclined with Philippine culture and arts could still be improved to better understand and explore the differences between the findings.

\section{Acknowledgements}

The researchers would like to express their gratitude to the National Commission for Culture and the Arts (NCCA), Philippines, and Espiritu Santo Parochial School of Manila, Inc., Philippines.

\section{References}

Abinuman, A. (2017). What's wrong with Filipino art and why is it under-appreciated? Mandaluyong City, Philippines: Candy. Retrieved from https://www.candymag.com/lifestyle/what-s-wrong-with-filipino-art-and-why-is-itunder-appreciated-a1580-20170722 
Ahmed, T. S. A. (2017). Assessment of students' awareness of the national heritage (Case study: The preparatory year students at the University of Hail, Saudi Arabia). Cogent Social Sciences, 3(1). http://dx.doi.org/10.1080/23311886.2017.1306202

Baraceros, E. L. (2016). Practical research 2. Philippines: Rex Book Store, Inc.

Chiakiamco, C. (2010). The struggle for Philippine art - then and now. Philippines: Philstar Global Corp. Retrieved from https://www.philstar.com/lifestyle/arts-andculture/2010/05/17/575439/struggle-philippine-art-then-and-now

Creswell, J. W. (2012). Educational research: Planning, conducting, and evaluating quantitative and qualitative research (4th ed). Upper Saddle River, NJ: Pearson Education.

Creswell, J. W. (2009). Research design: Qualitative, quantitative, and mixed methods approaches (3rd ed). USA: SAGE Publications, Inc.

David, E .J .R. (2013). Brown skin, white minds: Filipino-American postcolonial psychology. Charlotte, North Carolina, United States: Information Age Publishing.

Desirazu, N. (2019). The importance of art appreciation. Bangalore: EducationWorld. Retrieved from https://www.educationworld.in/the-importance-of-art-appreciation/

Eliasson, O. (2016). Why art has the power to change the world. Switzerland: World Economic Forum. Retrieved from https://www.weforum.org/agenda/2016/01/why-arthas-the-power-to-change-the-world/

Ishiguro, C., Yokosawa, K., \& Okada, T. (2016). Eye movements during art appreciation by students taking a photo creation course. Frontiers in Psychology, 7(1074). https://doi.org/10.3389/fpsyg.2016.01074

Lazarus, R. S. (1991). Progress on a cognitive-motivational-relational theory of Emotion. American Psychologist, 46(8), 819-834.

Leder, H., Gerger, G., Dressler, S., \& Schabmann, A. (2012). How art is appreciated. Psychology of Aesthetics, Creativity, and the Arts, 6(1), 2-10. https://doi.org/10.1037/a0026396

Matamoros, S. P. \& Sumi, A. (2017). Spanish artistic appreciation methodology in Japan: Learning own culture through art. Going to art museum with kindergarten children. Memoirs of the Faculty of Human Development University of Toyama, 12(1), 21-40.

Mateo, F. V. (2016). Challenging Filipino colonial mentality with Philippine art. (Unpublished master's thesis). The University of San Francisco. https://repository.usfca.edu/thes/196

Mercado, A. (2018). Is the Philippines still interested in contemporary art? Philippines: Philstar Global Corp. Retrieved from https://www.philstar.com/lifestyle/arts-andculture/2018/12/03/1873577/philippines-still-interested-contemporary-art

National Commission for Culture and the Arts (2016). Arts awake: Measuring the state of Philippine culture. Cebu City, Philippines: SunStar Publishing Inc. Retrieved from https://www.sunstar.com.ph/article/68334/Lifestyle/Arts-awake-Measuring-the-stateof-Philippine-culture

Nova Southeastern University (2020). Mixed methods. USA: Abraham S. Fischler College of Education and School of Criminal Justice, Nova Southeastern University.

Oclos, A. (2018). Archie Oclos: Social awareness through street art and the beauty and chaos of Philippine life. Native Province. Retrieved from https://www.nativeprovince.com/blogs/news/archie-oclos

Papouli, E. (2017). The role of arts in raising ethical awareness and knowledge of the European refugee crisis among social work students. An example from the classroom. Social Work Education, 36(7), 775-793. http://doi.org/10.1080/02615479.2017.1353074 
Pelowski. M., Markey, P. S., Lauring, J.O., Leder, H. (2016). Visualizing the impact of art: An update and comparison of current psychological models of art experience. Frontiers in Human Neuroscience, 10(160). http://doi.org/10.3389/fnhum.2016.00160

Perez, M. J. V. \& Templeza, M. R. (2012). Local studies centers: Transforming history, culture and heritage in the Philippines. IFLA World Library and Information Congress. Retrieved from https://www.ifla.org/past-wlic/2012/180-perez-en.pdf

Postma, S. (2018). Recovering beauty in art. Scott Postma. Retrieved from https://www.scottpostma.net/2018/04/25/recovering-beauty-in-art/

Rudd, M. A. (2015). Awareness of Humanities, Arts and Social Science (HASS) research is related to patterns of citizens' community and cultural engagement. Social Sciences, 4(2), 313-338. https://doi.org/10.3390/socsci4020313

Scherer, K. R., Shorr, A. \& Johnstone, T. (ed) (2001). Appraisal processes in emotion: theory, methods, research. Canary, NC: Oxford University Press

Sova, R. B. (2015). Art appreciation as a learned competence: A museum-based qualitative study of adult art specialist and art non-specialist visitors. Center for Educational Policy Studies Journal, 5(4), 141-157.

Tabuena, A. C. (2019). Effectiveness of classroom assessment techniques in improving performance of students in music and piano. Global Researchers Journal, 6(1), 68-78.

Tabuena, A. C., Bartolome, J. E. M. B. \& Taboy D. K. R. (2020). Preferred teaching practices among junior high school teachers and its impact towards readiness of grade seven students in the secondary school. International Journal of Trend in Scientific Research and Development, 4(4), 588-596. http://doi.org/10.5281/zenodo.4105703

Untivero, D. (2017). Protecting our Filipino heritage. Tatler Asia Limited. Retrieved from https://ph.asiatatler.com/life/Protecting-Our-Filipino-Heritage

Vanner, C. \& Kimani, M. (2017). The role of triangulation in sensitive art-based research with children. Qualitative Research Journal, $17(2), \quad 77$ 88. https://doi.org/10.1108/QRJ-12-2016-0073

Watzlawick, P., Weakland, J., \& Fisch, R. (1974). Change: Principles of problem formation and problem resolution. NY: Norton

Zimmermann, K. A. (2017). What is culture? Live Science. Retrieved from https://www.livescience.com/21478-what-is-culture-definition-of-culture.html 